Geology, Geophysics \& Environment • 2012 • Vol. 38 • No. $1 \bullet 51-68$

http://dx.doi.org/10.7494/geol.2012.38.1.51

\title{
ON THE CONVERGENCE OF WORKINGS AND THE PURPOSE OF WORKING OBSERVATIONS IN SALT MINES
}

\author{
O konwergencjach wyrobisk i celu ich obserwacji \\ w kopalniach soli
}

Grzegorz KORTAS

Instytut Mechaniki Górotworu PAN; ul. Reymonta 27a, 30-059 Kraków;

e-mail: kortas@img-pan.krakow.pl

\begin{abstract}
: in this paper, the author has presented the definitions of convergence as a stream of displacement vector field. The author has presented equations of the convergence of workings (chambers, caverns), in the shape of geometric primitives, as well as identified and described the stages of convergence development in time. Basic principles of convergence are discussed, associating main convergences in a rectangular cavern with its dimensions and volumetric convergence. The current status of knowledge has been used for the formulation of the objectives of conducting convergence measurements in underground salt mines. The description of the convergence stages and the study of a rectangular chamber are educational in nature, while the identified objectives of observations can be applied for designing convergence observations and interpretation of results.
\end{abstract}

Key words: convergence, room closure, creep compliance

Treść: W pracy przedstawiono definicje konwergencji jako strumienia pola wektorowego przemieszczenia. Określono wzory na konwergencję wyrobisk w kształcie prymitywów geometrycznych oraz wyodrębniono i scharakteryzowano fazy rozwoju konwergencji w czasie. Omówiono podstawowe zasady zaciskania wyrobisk, wiążące główne konwergencje w komorze prostopadłościennej z jej wymiarami i konwergencją objętościową. Dotychczasowy stan wiedzy wykorzystano do sformułowania celów prowadzenia pomiarów konwergencji w podziemnych kopalniach soli. Opis faz konwergencji i studium konwergencji w prostopadłościennej komorze mają walory poznawcze, a wyłonione cele obserwacji mogą być wykorzystane przy projektowaniu obserwacji konwergencji i interpretacji ich wyników.

Słowa kluczowe: konwergencja, zaciskanie, podatność na pełzanie 


\section{INTRODUCTION}

After the catastrophic flooding of the Wapno Salt Mine in 1977, survey of convergence became a widely applied method of identification of the local rock mass movement in the Polish salt mines. The author of this paper was the initiator of such research in the Solno, Kłodawa, Wieliczka, and Bochnia salt mines. Networks of measuring stations were established in multi-level chambers and many galleries at various depths. in the initial period, convergence measurements were directed to the recognition of the measurement methods and of the values of displacements in various mining conditions.

The results of observations and convergence were presented in many works (e.g. Kortas \& Józefko 2001, Kortas 2004, Bieniasz \& Wojnar 2007, 2008, Maj 2007a, 2009).

In recent years, the need of convergence survey increased owing to the development of numerical methods of geo-mechanical calculations for which the results of observations can become the source of obtaining model parameters (in Poland e.g. Tajduś 1990, Majcherczyk et al. 2006, Maj 2007a, 2007b, 2009, Tajduś 2007). A lot of practical examples of the use of displacement and convergence observations were presented in the works associated with underground fuel storage facilities or radioactive waste deposition in salt workings (in Sandia National Laboratories Reports concerning Waste Isolation Pilot Plant, USA), and recently also in the evaluations of the shaping of geo-mechanical conditions creating water hazards (Flisiak et al. 1997, Ocena... 2011).

When looking for effective means of using the convergence survey for the purpose of protecting historical salt mines, a research project financed by the Wieliczka Salt Mine was conducted in 2011. Some of that project results developed by the author have been used in this paper.

\section{CLOSURE OF SALT MINE WORKINGS}

Closure is the phenomenon caused by gravitation and it consists in deformation of a void, with change in the volume $k_{V}$ and shape $k_{S}$.

Closure is measured by volumetric convergence. Using the Ostrogradzki-Gauss theorem, we can define that term by the stream of vector field of displacement $U$, with the coordinates $u, v, w$ crossing the directed surface $\Omega$ :

$$
k_{V}=\oiint_{\Omega_{x y z}} U d \Omega=\iint_{\Omega_{y z}} u d y d z+\iint_{\Omega_{z x}} v d z d x+\iint_{\Omega_{x y}} w d x d y
$$

Volumetric convergence can be subdivided into volumetric lateral convergence $k_{R}$ and volumetric vertical convergence $k_{H}$, or:

$$
k_{V}=k_{R}+k_{H}, \quad k_{R}=\iint_{\Omega_{y z}} u d y d z+\iint_{\Omega_{z x}} v d z d x, \quad k_{H}=\iint_{\Omega_{x y}} w d x d y
$$


In two-dimensional space $\mathrm{XZ}$, for $v=0$, the definition of surface convergence can be recorded as a sum of surface horizontal and vertical convergences:

$$
k_{P}=\oint_{\Omega_{x z}} \boldsymbol{U} d \Omega=\int_{\Omega_{x}} w d x+\int_{\Omega_{z}} u d z
$$

Linear convergence of a section is defined as a difference of its boundary displacements $w_{1}$ and $w_{2}$, or:

$$
k_{h}=w_{2}-w_{1} .
$$

The convergence $k$ is expressed in volume units, field area or length. When convergence is divided by the workings' dimensions (spatial, surface or linear), non-dimensional relative convergence $\xi$ is obtained (expressed in deformation units or per milles).

\section{Closure phases and workings' convergence}

In the medium which shows viscous properties, like in the case of the rock salt mass, closure is a time-space process, and convergence is a function of time from the development of workings $t_{0}$ to their complete closure. Therefore:

$$
\lim _{t \rightarrow \infty} \xi(t)=-1 \text { lub } \lim _{t \rightarrow \infty} \xi(t)=-1000 \%
$$

however, the convergence increment in the period of measurements from $t_{1}>t_{0}$ to $t_{2}$ is the following:

$$
\xi(\Delta t)=\xi\left(t_{2}\right)-\xi\left(t_{1}\right) .
$$

The development of workings inside a salt medium causes the diversification of primary uniform main stress. The rock mass deformation increases in time, with increasing equalization of main stresses, leading to workings' closure. During creep action, the velocity of convergence is slowing and it stops after complete closure. At that time rock mass regains the hydrostatic state of stress.

We can distinguish three phases of closure (Fig. 1):

- In the first phase when the workings are developed, the main stress differences (being the largest in the middle of chamber walls) are increasing with time; this phase ends with the appearance of maximum convergence rate at point $\mathrm{P}$ (Fig. 1).

- In the second main phase of closure, the differences of main stress and convergence rate are decreasing; usually, the convergence rate is noticed only after a long period of observation; the dependence of convergence on time is described by a non-linear function, although the velocity of convergence is practically constant in a short period of observation.

- In the third phase (from point $\mathrm{R}$ in figure 1), closure continues with an additional action from the supports that have occurred when the deformation process and strength excess have caused contact with opposite chamber walls; the third phase of closure is ended with the conclusion of the closure process.

Volumetric deformation in rock mass around the workings in the first and second phases are extensions that change their mark in the third phase and turn into closure. 
In the second and third phases, convergence is a function of time, described for example with the power function of the type:

$$
\xi_{V}(t)=-1000 \% \circ\left[1-\left(\frac{t-t_{P}}{t_{j}}\right)^{\mu}\right]
$$

where $t_{P}$ is the time of the start of the second phase and $\mu$ is the parameter of the closure process (e.g. $\mu=-0.3$ ), $t_{j}$ is the time unit (e.g. 1 year). In the third phase the $\mu$ value increases (e.g. to -0.2 ) as a result of the support effect.
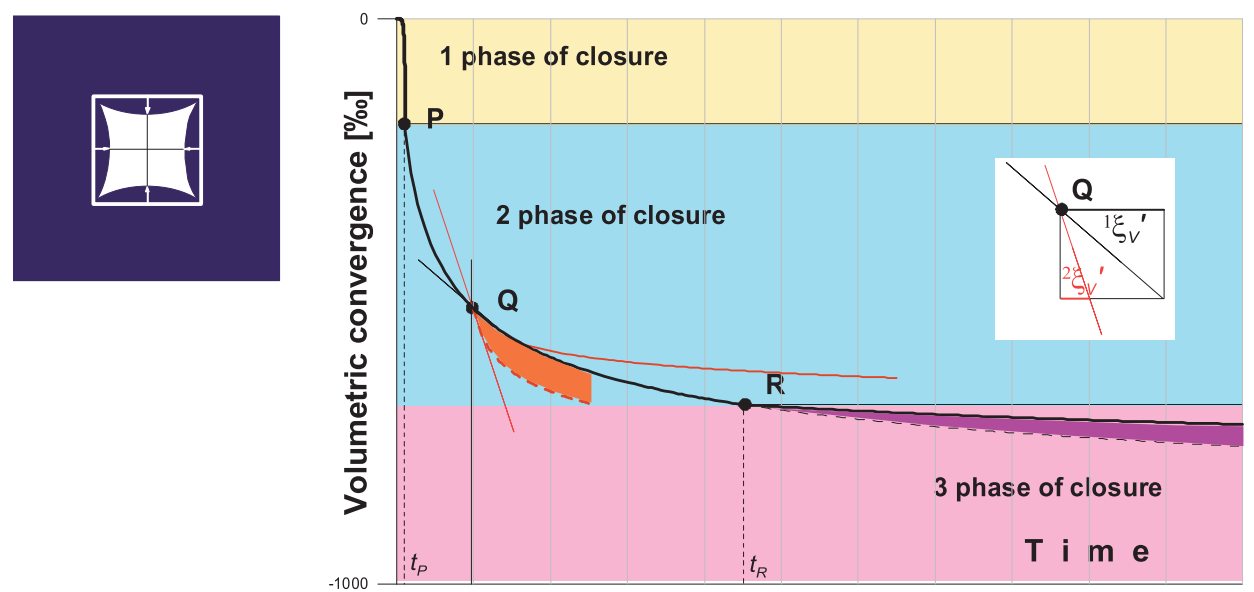

Fig. 1. Volumetric convergence in three chamber closure phases

Fig. 1. Konwergencja objętościowa w trzech fazach zaciskania wyrobiska

Continuity is a characteristic feature of closure when the efforts are lower then of rock mass strength. Discontinuity can indicate the excess of the rock mass strength. That is marked by a sudden change of the convergence rate (e.g. in point $\mathrm{Q}$ in figure 1). in that case, the convergence derivatives $d \xi(t) / d t$, left-hand and right-hand ones, are different (Fig. 1), and the change of the stress state is indicated by the increase of the convergence rate $\left(\xi^{\prime}\right)$ :

$$
\Delta \xi_{V}^{\prime}={ }^{1} \xi_{V}^{\prime}-{ }^{2} \xi_{V}^{\prime}
$$

Also convergence rate can be caused by a change of physical or mining conditions resulting for example from rock mass cracking or watering, chamber filling, shoring, or conducting mining operations close to the observation station.

\section{Convergence of geometric primitives}

Let's consider closure in a uniform rock mass of separated workings with primitive forms of sphere, cylinder, and layer (Fig. 2). Create by mining of a spherical working, with 
the diameter of $d$, causes the same state of stress in the rock mass with uniform distances from the working shape. Maximum displacements occur in the spherical envelope and they decrease to zero with distance from their. Relative volumetric convergence is directly proportional to the linear convergence $k$ and equals $\xi_{V}=3 k / d$.
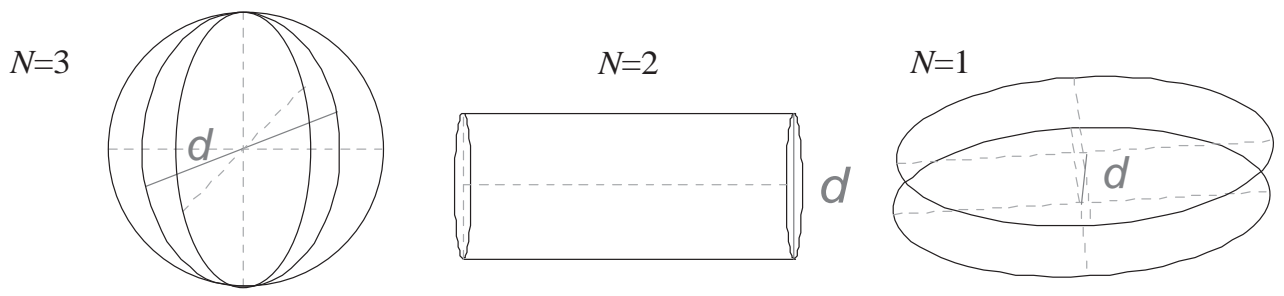

Fig. 2. Geometric primitives

Fig. 2. Prymitywy geometryczne

In the surrounding areas of a spherical horizontal gallery, with the diameter $d$, in equal distance from its horizontal axis, stress and displacement are uniform. Closure causes the change of the surface of cross-section, and closure is expressed by relative surface convergence $\xi_{P}=2 \mathrm{k} / \mathrm{d}$. For small cross dimensions, in respect of the longitudinal dimension, longitudinal convergence is insignificant, and relative volumetric convergence is equal to surface convergence $\xi_{V}=\xi_{P}$.

The simplest object has the form of a longwall, with the height of $d$. Its closure is expressed only by convergence in the perpendicular direction in expansion of the plane with infinite this dimensions $\xi_{V}=\xi_{d}=k / d$, because cross convergences are insignificant owing.

A general equation which determines the dependence of relative and volumetric convergence on linear one of those geometric primitives is expressed by proportionality of linear convergence to the dimension $d$ :

$$
\xi_{V}=N(k / d)
$$

and the number of space dimensions $N \in[3,2,1]$ constitutes proportionality coefficient $N$. The relationship (7) is not fulfilled in a cubicoid chamber or gallery.

\section{Dependence of volumetric convergence on the cubicoid shape of the chamber}

The relationships between convergences in a cubicoid chamber depend on dimensional diversity. They are determined by geo-mechanical model calculations resulting in a functional description of the relationships between main relative linear convergences measured at the crossings of symmetry planes and volumetric convergence. Functional relationships for cubicoid chambers with horizontal and vertical walls are determined on the basis of model 
examinations of the elastic-viscous medium in the conditions described in the paper entitled Ruch górotworu... (Kortas red. 2004). in this section convergence of 30 cubicoid chambers with different dimensions was analysed.

\section{The principle of proportionality and the position of a cubicoid chamber}

Expression of convergence in relative values is a consequence of the principle of proportionality (Fig. 3) stating that a proportional change of chamber dimensions does not change main relative convergences. According to that principle, main relative convergences of cubicoid chambers with various volumes are the same. The principle of proportionality is not completely accurate owing to the increase of load, with depth.
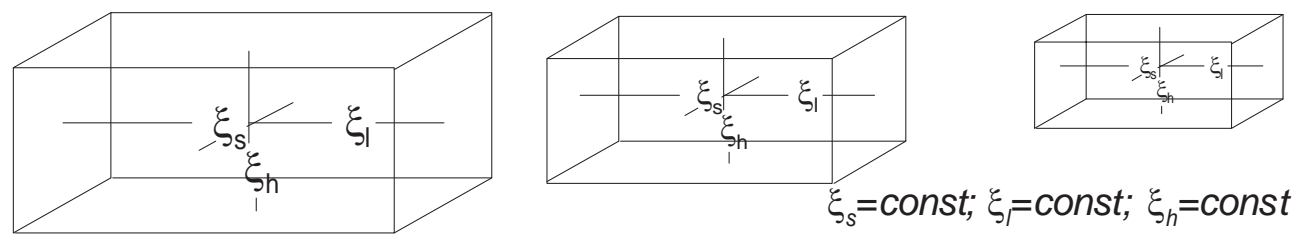

Fig. 3. Proportional change of chamber dimensions

Fig. 3. Proporcjonalna zmiana wymiarów komory

The dependence of relative volumetric convergence on relative linear convergences is expressed by the following relationship:

$$
\xi_{V}=C\left(\xi_{s}+\xi_{h}+\xi_{l}\right)
$$

where constant $C<1$ depends on the convexity of deformed walls and the chamber volume to a large extent. If the wall displacement in perpendicular direction was uniform (that is without convexity), then $C=1$.

Model studies indicated that the influence of chamber volume on the coefficient $C$ can be expressed by an approximation function in the form of a power dependence (9), where $V_{j}$ is a dimensional unit (e.g. $V_{j}=1 \mathrm{~m}^{3}$ ):

$$
C(V)=0.534\left(V / V_{j}\right)^{\alpha}
$$

The dispersion of calculation results and the approximation function function are shown in figure 4 . The power exponent of $\alpha=0.026$ is very small, close to 0 . in simplified convergence analyses $\alpha=0$ and the value of $C=0.63$ is used. 


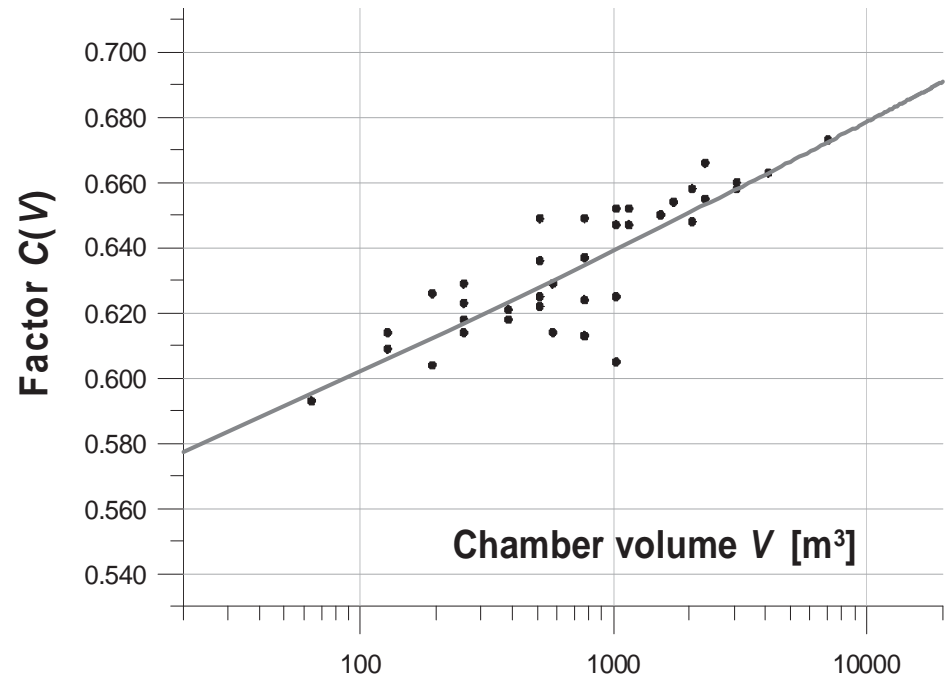

Fig. 4. Results of calculations, with approximation

Fig. 4. Wyniki obliczeń numerycznych i ich aproksymacje

The relationship between volumetric convergence and main convergences of a cubicoid chamber, with the vertical side $h$ and horizontal sides $s$ and $l$, has the following form:

$$
\xi_{V}=\frac{k_{v}}{V}=0.534\left(\operatorname{slh} / V_{j}\right)^{0.026}\left(\xi_{s}+\xi_{l}+\xi_{h}\right)
$$

From equation (10), we can infer the principle of independence of convergence from the chamber's position stating that when verticality of one of chamber sides is preserved (Fig. 5), a change of the cubicoid chamber position does not cause a change of its volumetric convergence.
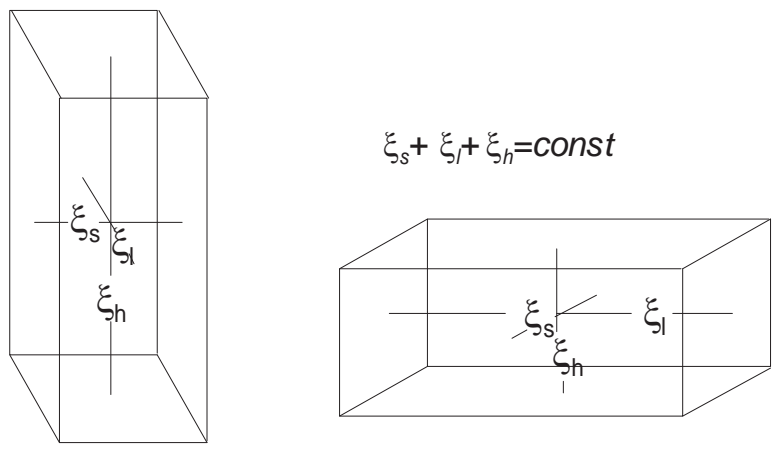

Fig. 5. Change of the cubicoid chamber position, when the side dimensions are the same

Fig. 5. Zmiana położenia prostopadłościennej komory o tych samych wymiarach boków 
In the event of a change of the chamber's position, mutual relationships of the main relative and linear convergences will change, although the total value will remain constant.

\section{Influence of the cubicoid chamber side prolongation on main convergences}

A change of one of the cubicoid chamber's dimension will affect its shape. With the constant length of the different sides $s, h$ ( $s / h$ being constant), let's change the length of the side $l$ from $l_{1}$ to $l_{2}\left(n=l_{2} / l_{1} \neq 1\right)$. The main convergences relationships for the power constant of $c>0$ will be expressed by the following relationships:

$$
\xi_{s} / \xi_{l}=\left(l_{2} / s\right)^{c}, \quad \xi_{h} / \xi_{l}=\left(l_{2} / h\right)^{c}, \quad \xi_{s} / \xi_{h}=(h / s)^{c}
$$

According to the principle of constant convergence proportion (Fig. 6), the relationship of the main convergences does not depend on the length of the perpendicular side of the cubicoid chamber.

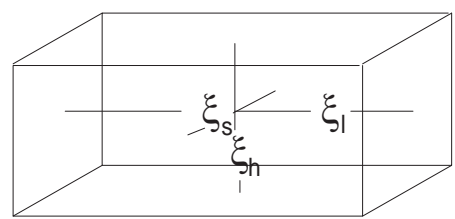

$\xi_{s} \xi_{h}=$ const

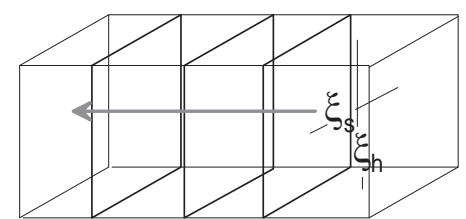

Fig. 6. Prolongation of the length of one of the cubicoid chamber's sides

Fig. 6. Zwiększanie długości jednego z boków prostopadłościennej komory

The proportions of main convergences in which the changing side $l$ participates depend on the change of length. Let it be expressed by the coefficient $n$, as follows:

$$
\xi_{s} / \xi_{l}=n^{c}\left(l_{1} / s\right)^{c}, \quad \xi_{h} / \xi_{l}=n^{c}\left(l_{1} / h\right)^{c}
$$

If the length of the side $l$ is changing $\left(l_{2} / l_{l}=n \neq 1\right)$, the relationships of main convergences $\xi_{s} / \xi_{l} \mathrm{i} \xi_{h} / \xi_{l}$ are either increasing or decreasing, proportionally to the value of constant $n^{c}$. The increase of $l$ causes the increase of (negative) convergences $\xi_{s}$ and $\xi_{h}$ and the decrease of convergence $\xi_{l}$, with the preservation of the constant proportion between them. According to the principle of three convergences, the increase of a side length causes a decrease of main convergence in the respective direction and increase of main convergences in perpendicular directions.

For that reason, in high chambers, horizontal convergences dominate in volumetric convergence, while in long horizontal chambers, they are dominated by convergences in the 
directions which are perpendicular to the longer dimension, e.g. $\xi_{l}$. With the increase of the length of the side $l$, the convergence $\xi_{l}$ is decreasing to zero $\left(\lim _{l \rightarrow \infty} \xi_{l}=0\right.$ ), with the cubicoid chamber's form changing into a gallery, with a rectangle cross-section.

\section{Gallery and wall working as special forms of a cubicoid chamber}

A horizontal gallery is a special shape of a cubicoid chamber in which the dimension $l$ is much larger than the cross dimensions $s$ and $h$, or:

$$
\xi_{l}=\xi_{h}(h / l)^{c} \approx 0 \text { or } \xi_{l}=\xi_{s}(s / l)^{c} \approx 0
$$

The shape rule is reduced then to the following dependence:

$$
\xi_{s} / \xi_{h}=(h / s)^{c}
$$

The reduction of essential dimensions from three to two causes that the relative volumetric convergence of a gallery is approximately equal to the relative surface convergence $\xi_{P}$, or the negative increase of the cross-section surface of the gallery because:

$$
\xi_{V}=\xi_{P}=C\left(\xi_{s}+\xi_{h}+\xi_{l}\right)=C\left(\xi_{s}+\xi_{h}\right), \text { if } \lim _{l \rightarrow \infty} \xi_{l}=0
$$

According to the shape rule, we can demonstrate that, for a very long gallery $(l \rightarrow \infty)$, the increase of its width $(s \rightarrow \infty)$ leads to the transformation of the gallery into a longwall, with the height $h$, while relative volumetric convergence is replaced by linear one. Therefore, a gallery or a winze and a longwall working are geometrical degenerated forms of a cubicoid chamber.

Similarly to a chamber working, surface convergence of a gallery with a rectangular cross-section can be calculated on the basis of only one known main convergence. Therefore, for $\psi=s^{c}+h^{c}$ :

$$
\xi_{s}+\xi_{h}=\xi_{s} \frac{\psi}{h^{c}}=\xi_{h} \frac{\psi}{s^{c}}
$$

And the surface convergence of a gallery is expressed by:

$$
\xi_{P}=C\left(\xi_{s}+\xi_{h}\right)=C \xi_{s} \frac{\psi}{h^{c}}=C \xi_{h} \frac{\psi}{s^{c}}, \quad C \approx 0.63
$$

If height is a longer dimension of a working, which concerns shafts and winzes, the increase of stress with depth causes that the place of extreme horizontal convergence occurrence is found under the bottom, and then the constant $C$ is transformed into the function $C=C(h)$. 


\section{PURPOSE OF CONVERGENCE SURVEY IN UNDERGROUND SALT MINES}

Convergence survey is a simple method of recording local movements in workings because they do not require measurement network or linking with steady points. Convergence is a result of mining and geological conditions and stress field in the rock mass. The observed displacements depend considerably on the form of working and locations of measurement bases. Identification and accounting of such factors in measurement results should be one of the basic purposes of taking convergence measurements, as well as a condition of correct result interpretation. Measurement results should be collected in date bases with digital properties.

\section{Recognition of chamber closure symptoms}

When starting to recognize the chamber closure symptoms, we assume that unrecognised geo-mechanical conditions are not essential for the observation results. The measurement bases are then usually set in the available places.

The measurements are made in uniform periods, independently of the convergence rate, while measurement accuracy is improved by:

- preliminary recognition of closure to determine further expansion of the measurement station,

- recognition of convergence increase in time to establish effective measurement frequency,

- checking of various measurement methods,

- determination of mean errors of the assumed measurement method.

After a cycle of measurements, it is necessary to define the purpose of further observations, with suitable adjustment of the measurement method and frequency.

Determination of accuracy is a condition of the measurements' engineering correctness, especially when the measurement mean errors are of the same or bigger order as the convergence increase in time between observations.

\section{Convergence as an indicator of local rock mass activity: special objects}

Determination of local activity should be directed to the identification of the behaviour of the object of observations, e.g. a specific factor of geological and mining conditions, not necessarily a dominating one. The measurement base locations should be documented geodetically, and the results presented in the form of convergence dependence on time.

The observation results will be only a signal of the geo-mechanical processes which will remain non-recognized. We do not resolve the relationships between hazards and geo-mechanical conditions either. 
Various objects or special places, located mainly in chambers, can be subjected to measurement. For example we observe pillar or room and pillar structure deformations, the influence of rock mass water content, the changes caused by discontinuous processes occurring in the vicinity of measurement bases, the shoring effects, the movement on the formations' lithological boundaries, the behaviour of water, shaft and landslide zones etc. Also the study of the chamber protection effectiveness should be the purpose of measurements. in that case, we compare the convergence before and after protection construction, e.g. by wooden choc, roof anchoring, implementation of other types of shoring, or filling of adjacent chambers.

The results of such observations concern exclusively the symptoms of object (zone) behaviour only in a specific place. Observations of considerable convergence rate changes indicate that the stress condition has changed. Decision on how essential that effect is requires the conclusion that the convergence rate change is larger than the limited error. Smaller changes belong to the "noise" area caused by inaccurate measurements.

Examination of the multi-horizontal structure deformation of a chamber-and-pillar mine is an example of how we can use observations and main linear convergences. Let's assume that the measurement results will consist of the convergence and deformation velocity of a section of mine structure, with chambers, pillars, and shelves, presented in figure 7.

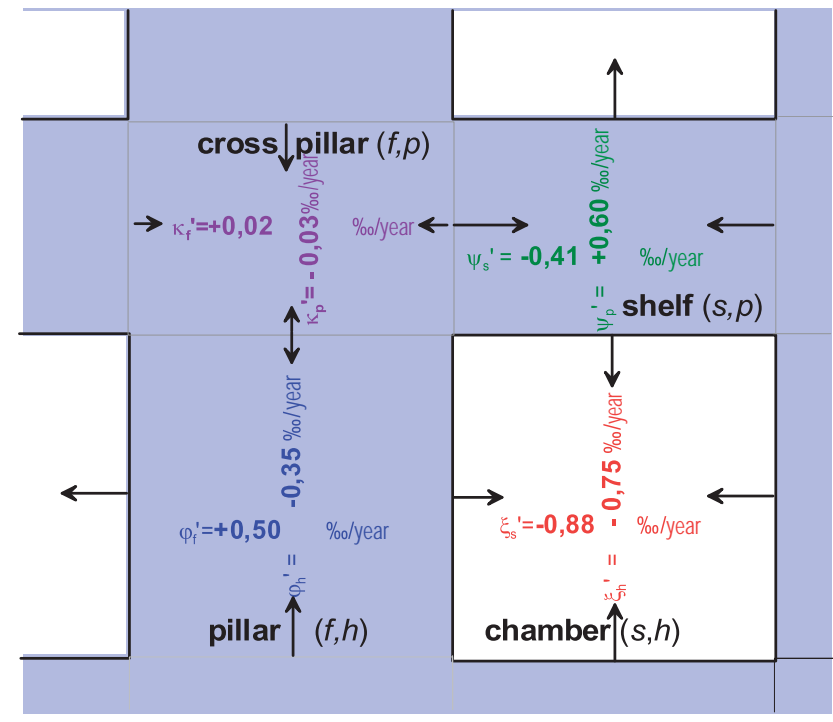

Fig. 7. Convergence and deformation velocity values in vertical cross-section

Fig. 7. Wartości prędkości konwergencji i deformacji

Since the length of chambers, pillars, and shelves in the direction which is perpendicular to the cross-section is much larger than the dimensions in the cross-section plane $(s=h=f=15 \mathrm{~m}$ and $p=10 \mathrm{~m}$ ), we can apply equation (17) to determine the chamber's 
volumetric convergence. When calculating the working deformation, we can initially omit in the first approximation non-parallel displacement distribution in the pillar and shelf bases.

Therefore:

- the chamber's volumetric convergence velocity for $C=0.63$ will be the following:

$$
K \xi_{V}^{\prime}=0.63 \cdot\left(\xi_{s}^{\prime}+\xi_{h}^{\prime}\right)=0.63 \cdot(-0.88-0.75) \% \text { olyear }=-1.02 \% \text { year, }
$$

- the pillar's volumetric deformation velocity for $C=0.63$ will be following:

$$
F \xi_{V}^{\prime}=0.63 \cdot\left(\varphi_{s}^{\prime}+\varphi_{h}^{\prime}\right)=0.63 \cdot(+0.50-0.35) / \text { year }=-0.04 \% \text { o } / \text { year, }
$$

- the shelf's volumetric deformation velocity for $C=0.63$ will be following:

$$
P \xi_{V}^{\prime}=0.63 \cdot\left(\psi_{s}^{\prime}+\psi_{h}^{\prime}\right)=0,63 \cdot(+0.60-0.41) \% \text { orok }=-0.03 \% \text { o/year, }
$$

- cross pillar's deformation velocity for $C=0.63$ will be following:

$$
o \xi_{V}^{\prime}=\left(\kappa_{s}^{\prime}+\kappa_{h}^{\prime}\right)=(+0.02-0.03) \% \text { olyear }=-0.01 \% \text { olyear. }
$$

Deformation of a structure section, as the weighted sum of convergence and deformation:

$$
\begin{gathered}
s \xi_{V}^{\prime}=\left[{ }^{K} \xi_{V}^{\prime} \cdot(15 \cdot 15)+F \xi_{V}^{\prime} \cdot(15 \cdot 15)+{ }^{P} \xi_{V}^{\prime} \cdot(15 \cdot 10)+o \xi_{V}^{\prime} \cdot(15 \cdot 10)\right] /[225 \cdot 2+150 \cdot 2]= \\
=[(-1.02-0.04) \cdot 225+(-0.03-0.01) \cdot 150] / 750=-0,336 \% \text { o/year }
\end{gathered}
$$

Assuming constant convergence and deformation velocity during 30 years, volumetric deformation of the structure will reach about $-9.8 \%$ per year.

\section{Contribution of roof and floor movements to convergence}

Identification of the contribution of roof and floor movements to vertical convergence is quite difficult owing to considerable errors made in linking measurements with the points of constant height. A suitable method of determining the roof movement consists in the measurement of differences in height between the points on the roof and a point on the chamber's wall which is often associated with steady points. That method is justified when the roof lowering values exceed limit errors of determining the height of the intermediate link point. To fulfil that condition, it is necessary to extend the time between subsequent measurements.

To determine the symptoms of fall of roof hazard, it may be enough to establish the progress in time of relative vertical displacement of the roof, with local linking with the points on the rock, in the distance which corresponds at least to several times the maximum of the chamber's dimension. That could be e.g. a benchmark set in the middle of the gallery height, separated from the observed chamber. 
Periodic level measurements of the steady points on the chamber's roof and floor, without linking to other steady points allow for correct determination of the chamber's vertical volumetric convergence component, without deciding about the contribution of the roof and floor movement to convergence. The horizontal components, resulting from the horizontal movement of walls, should be then determined by taking measurements on several horizontal bases. Owing to low costs of such measurements and possible high accuracy, e.g. with the application of precise levelling, it is recommended to apply this method, especially when the chamber's roof or bottom surface is much larger than that of the walls.

\section{Determination of the rock mass's compliance to creep: measurements taken in galleries and winzes}

There is a number of geo-technical methods which are used for the determination of the elastic rock mass properties. Convergence observations in salt mines should be designed for the determination of the rock mass's rheologic properties. Convergence measurements in the second phase of closure can turn out to be a simple method of rock mass's creep studies. When designing the measurement stations, we are looking for such conditions in which chamber convergence and rock mass deformations depend on the uniform adjacent rock mass properties.

Determination of compliance can be attained by direct or analytical methods. in the direct method, based on the convergence observation results, we can identify typical lithological conditions occurring in the rock mass and assign the convergence rates to them. The scale obtained in that manner will be useful for the qualitative geological classification of the rock mass, although it cannot be used directly in geo-mechanical calculations.

By application of the FEM analytical method, we determine the geo-mechanical properties of rocks, or the values of the geo-mechanical model parameters, including primarily the compliance to creep of the studied rock mass area, using a back analysis. The results of such determinations can be used later in other geo-mechanical calculations. That will replace rheological studies of rock samples whose results, although essential for our knowledge, cannot be directly applied in the mining structure calculations.

Correct conducting of convergence observations and of the studies designed for the determination of rock mass compliance to creep by the analytical method requires the placement of measurement stations in a gallery or a winze of any dimensions, within homogenous rock mass, located in a distance from other types of chambers. The smaller the working, the smaller the zone which is not distorted by the influences of other types of chambers. Therefore, it is easy to find proper locations for observation station placement. That is why such stations are not placed in chambers. Measurement stations placed in galleries should use points mounted on gallery walls and in rock mass a distance form this walls (Fig. 8, there $a=h / 6$ ). The measurements bases of such stations can be limited to the distribution of points on a horizontal plane crossing the centre of the gallery. A sample rock mass rheological parameter calculation based on such measurements is presented by A. Maj (Maj 2007a). 


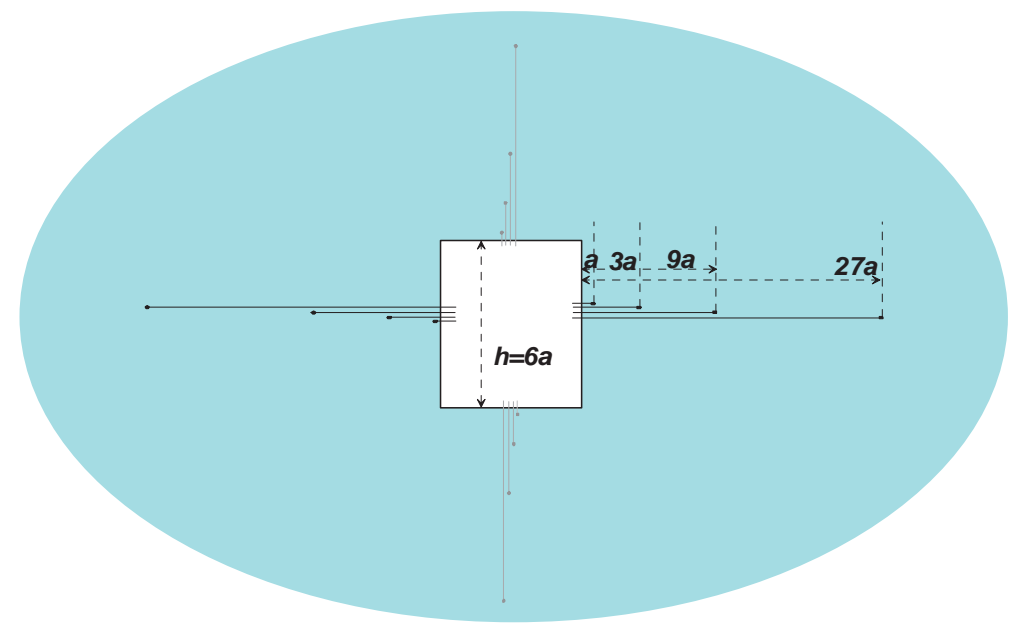

Fig. 8. A design of a station for measuring the rheological properties of rock mass

Fig. 8. Szkic projektu stacji do badania właściwości reologicznych górotworu

Convergence measurements should be designed for the determination of compliance to rock creeping in the vicinity of the historical parts of salt mines and in galleries crossing various rock mass lithological zones, as well as those crossing the areas that are flooded as a result of working filling with liquid materials.

\section{Use of convergence measurements for the recognition of geo-mechanical conditions in the vicinity of chambers}

The rock mass made active by working closure is proportional to the working dimensions. For that reason, chambers' volumetric convergences are characterized by the rock mass deformation activity in the space which is much larger than the surface convergence occurring in galleries or winzes. Therefore, volumetric convergences found in large-size chambers indicate the rock mass behaviour on a large scale.

Full recognition of geo-mechanical conditions is practically not possible in the zone of influence of the chamber workings. Identification of volumetric convergence by measurements can be useful for a preliminary evaluation of such conditions, usually by the comparison of measured convergence and calculated model convergence for the working having the same shape, within elastic-viscous medium model. The differences found between such convergences will characterize the deviation of the real geo-mechanical conditions from those assumed in model conditions. Next, by change of the model parameters, e.g. stiffness or compliance to creep, and back analysis, we can attain new compatibility of the calculations with results of measurements and finally define the physical reason of the analysed deviation. 


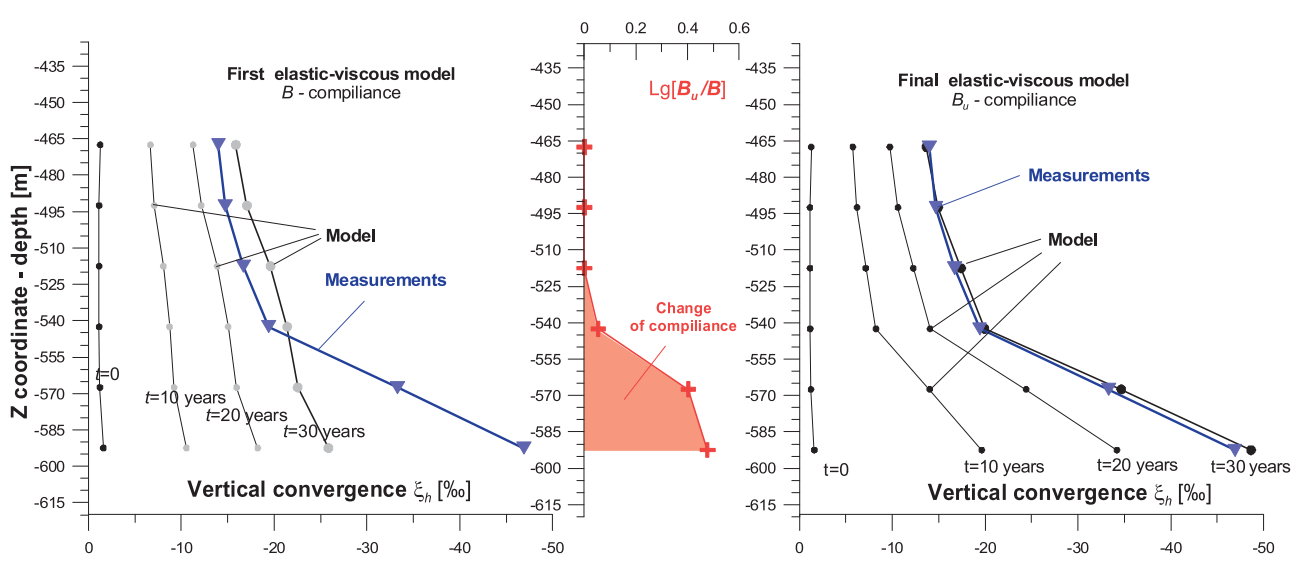

Fig. 9. Vertical convergence in Field 1 of the Kłodawa Salt Mine; measurements and a geo-mechanical model of the elastic-viscous medium

Fig. 9. Konwergencje pionowe w polu $1 \mathrm{w}$ kopalni Kłodawa, pomiar i model geomechaniczny ośrodka sprężysto-lepkiego

Figure 9 presents the results of vertical convergence measurements conducted in the field of multi-level room and pillar salt mine and the results of the correction of compliance of the parameter $B$ of the model to adjust the calculations to actual observations. In the paper on Ocena zagrożenia wodnego... (2011), it was found that such compliance was caused by exceeded strength of pillars in the first years after salt extraction.

\section{SUMMARY AND CONCLUSIONS}

1. The convergences observed in salt mines are the results of rock mass creeping processes in local geological and mining conditions, although specific data depend to a large extent on the shape of workings and the locations of measurement bases.

2. The three convergence phases of the closure working have been defined, with the identification of the main second phase in which convergence measurements are taken.

3. Volumetric convergence and its measure is a synthetic indicator of working closure; the same about surface convergence in case of longitudinal workings. Those types of convergence can be calculated by taking measurements of main linear convergences. in case of workings of more irregular shapes, accidental localization of linear measurement bases will not assure fully credible volumetric convergence calculations.

4. Several principles linking main linear convergences with cubicoid chamber dimensions and their relationships to gallery convergence have been formulated here for the first time. Those principles can be helpful in designing and interpretation of the convergence study results. 
5. The purposes of convergence observations have been presented and discussed, with distinguishing of preliminary exploration measurements, the observations of the symptoms of object closure (e.g. of pillars) and special zones (e.g. of shoring), and the observations of chambers' roof surface movements. It is recommended to continue measurements for the determination of rheological rock mass properties and geo-mechanical conditions in the vicinity of chambers by linking the studies with modelling of the chamber behaviour in the elastic-viscous medium.

6. The results of the present studies can be useful for more rational convergence measurements and subsequent recognition of geo-mechanical processes which cause the convergence of workings.

The authors would like to thank the managers of the Wieliczka Salt Mine for their kind assistance in giving access to documentary and archival materials.

\section{REFERENCES}

Bieniasz J. \& Wojnar W., 2007. Zarys historii pomiarów i wybrane wyniki obserwacji zjawiska konwergencji wyrobisk w pokładowych złożach soli. Gospodarka Surowcami Mineralnymi, 23 (special issue), 133-142.

Bieniasz J. \& Wojnar W., 2008. Analiza porównawcza deformacji poeksploatacyjnych kłodawskiego systemu komorowo-filarowego przy pionowym i ukośnym układzie wyrobisk. Gospodarka Surowcami Mineralnymi, 24, 3/2, 111-120.

Flisiak D., Flisiak J. \& Tajduś A., 1997. Geomechaniczne problemy projektowania podziemnych magazynów sprężonego powietrza dla energetyki. Biblioteka Szkoły Eksploatacji Podziemnej, 6, Kraków.

Kortas G. (red.), 2004. Ruch górotworu i powierzchni w otoczeniu zabytkowych kopalń soli. Wydawnictwo Instytutu Gospodarki Surowcami Mineralnymi i Energią PAN, Kraków.

Kortas G. \& Józefko L., 2001. Konwergencja komory Ważyn w zabytkowej kopalni soli Bochnia. Bezpieczeństwo Pracy i Ochrona Środowiska, 7-8 (83-84), 3-8.

Maj A., 2007a. Określenie konwergencji i właściwości lepkich górotworu solnego na przykładzie obserwacji w ZG Polkowice-Sieroszowice. Przegląd Górniczy, 6, 25-29.

Maj A., 2007b. Modelowanie konwergencji w oparciu o wyniki pomiarów geodezyjnych w kopalni Siedlec. W: Geotechnika w budownictwie i górnictwie, Oficyna Wydawnicza Politechniki Wrocławskiej, Wrocław, 451-457.

Maj A., 2009. Opracowanie modelu konwergencji wyrobisk w podziemnych kopalniach soli. Biblioteka Główna AGH, Kraków (Ph.D. Thesis).

Majcherczyk T., Małkowski P. \& Niedbalski Z., 2006. Ruchy górotworu i reakcje obudowy w procesie niszczenia skat wokół wyrobisk korytarzowych na podstawie badań ,in-situ”. Wyd. AGH WGiG, Kraków.

Ocena zagrożenia wodnego oraz warunków geomechanicznych w Kopalni Soli Kłodawa $w$ aspekcie zachowania bezpieczeństwa powszechnego oraz bezpiecznego prowadzenia ruchu zakładu górniczego. ZBP GeoConsulting, maj 2011, Kraków, Archiwum WUG, Katowice. 
Tajduś A., 1990. Utrzymanie wyrobisk korytarzowych w świetle wpływu czasu na naprężenia, odkształcenia i strefy zniszczenia w górotworze. Zeszyty Naukowe AGH, Górnictwo, 154, Wydawnictwa AGH, Kraków.

Tajduś K., 2007. Determination of mechanical parameters of strata under the influence of underground mining using „back analysis”. 8. Geokinematischen Tag, Verlag Glückauf $\mathrm{GmbH}$.

\section{Streszczenie}

Obserwacje konwergencji w polskich kopalniach soli należą do podstawowych pomiarów prowadzonych w celu określenia lokalnego ruchu górotworu. W pracy przedstawiono podstawowe definicje zjawiska konwergencji, zależności poszczególnych rodzajów konwergencji od formy wyrobisk prostopadłościennych oraz czasu. Uwzględniając te zależności, omówiono cel i sposoby obserwacji konwergencji w podziemnych kopalniach soli. W ostatnim rozdziale podano podsumowanie i wnioski z pracy.

Konwergencje definiuje się jako strumień pola wektorowego przemieszczenia określony wzorami (1)-(3). Na tej podstawie określa się zachowanie trzech prymitywów geometrycznych, wskazując, że konwergencję objętościową w przestrzeni trzy-, dwu- i jednowymiarowej określa wzór (7).

Związek konwergencji z czasem definiuje się w trzech fazach czasu (Fig. 1). W pierwszej fazie, w trakcie tworzenia się wyrobisk rosną naprężenia efektywne w otoczeniu wyrobiska i rośnie szybko konwergencja objętościowa; w drugiej fazie naprężenia efektywne maleją, a konwergencję opisuje funkcja potęgowa (5); w trzeciej fazie deformacje powodują powstanie wsporników z opadających skał, co powoduje dalszy spadek prędkości konwergencji, a po długim czasie prowadzi to do całkowitego zatrzymania procesu zaciskania wyrobiska.

Zależność konwergencji liniowych od kształtu prostopadłościennej komory przedstawia się za pomocą kilku zasad wiążących główne konwergencje liniowe z wymiarami prostopadłościennej komory. Z zasady proporcjonalności wynika, że proporcjonalna zmiana wymiarów wyrobiska nie zmienia jego względnych konwergencji głównych (wzór (8), Fig. 3). Niewielkie odchylenie od tej zasady powodowane jest głównie wpływem obciążeń masowych wzrastających z głębokością, co uwidacznia się w komorach o znacznej objętości (wzór (9), Fig. 4). Niezależność konwergencji objętościowej od położenia komory i jej obrotów o $90^{\circ}$ (Fig. 5) skłania do wniosku, że zmiana pozycji prostopadłościennej komory nie powoduje zmiany jej konwergencji objętościowej. Z zasady stałości proporcji konwergencji wynika, że stosunek konwergencji głównych nie zależy od długości prostopadłego do nich boku prostopadłościennej komory (wzór (11), Fig. 6). Zgodnie z zasadą trzech konwergencji (12) wzrost długości boku powoduje spadek konwergencji głównej w tym kierunku i wzrost dwóch konwergencji głównych w kierunkach prostopadłych.

Ze wzrostem jednego z wymiarów przy utrzymaniu prostokątnego przekroju wyrobiska poziomego komora prostopadłościenna przechodzi w chodnik, którego konwergencję powierzchniową wyrażają wzory (15)-(17), a przy utrzymaniu jednego wymiaru i wydłużeniu 
dwóch pozostałych tworzy się wyrobisko ścianowe, którego konwergencję wyraża tylko konwergencja liniowa.

Wstępne pomiary konwergencji służą rozpoznaniu zaciskania się wyrobiska w celu określenia dalszej rozbudowy stacji pomiarowej, prędkości konwergencji, sprawdzenia różnych metod pomiarowych i wyznaczenia błędów średnich przyjętego sposobu pomiaru. Po cyklu takich obserwacji należy zdefiniować i uzasadnić cel obserwacji. Warunkiem poprawności inżynierskiej rzetelnej obserwacji jest określenie dokładności pomiarów (błędów średnich w warunkach in situ).

Celem określenia lokalnej aktywności powinna być identyfikacja zachowania się obiektu obserwacji. Wyniki pomiarów będą wtedy sygnałem procesów geomechanicznych, których mechanizm pozostaje nierozpoznany. Obserwowane mogą być np. deformacje filarów, deformacja struktury komorowo-filarowej, wpływ zawodnienia górotworu, zmiany spowodowane procesami nieciągłymi w bliskim sąsiedztwie bazy pomiarowej, oddziaływanie obudowy, ruch przy granicach litologicznych utworów, zachowanie się tam wodnych, podszybia, stref zawałowych czy skuteczności zabezpieczenia komór. W taki przypadku porównywane są konwergencje przed wprowadzeniem i po wprowadzeniu zabezpieczenia, np. przez założenie kasztu, kotwienie stropu czy wprowadzenie innej obudowy lub też przez wypełnienie sąsiednich wyrobisk. Obserwacja znaczącej zmiany prędkości konwergencji wskazuje, że zmienił się stan naprężeń. Orzekanie o istotności tego efektu wymaga stwierdzenia, że zmiana prędkości konwergencji jest większa niż błąd graniczny jej wyznaczenia. Podano przykład wykorzystania obserwacji głównych konwergencji liniowych do badanie deformacji objętościowej struktury w wielopoziomowej komorowo-filarowej kopalni (Fig. 7).

Zaleca się wykorzystanie pomiarów konwergencji do określenia udziału ruch stropowego i spągowego w zaciskaniu komór o przeważającej poziomej rozległości.

Jednym z podstawowych celów pomiarów konwergencji jest określenie właściwości reologicznych skał solnych za pomocą pomiarów przemieszczeń punktów w górotworze i zaciskania konturu wyrobisk chodnikowych. Sposób założenia stacji pomiarowej przedstawiono na figurze 8. Wyniki takich pomiarów służą wyznaczeniu parametrów fizycznych ośrodka sprężystolepkiego poprzez analizę odwrotną przy wykorzystaniu metody elementów skończonych. Ze względu na niewielkie wymiary chodników tą metodą określać można podatność na pełzania różnych rodzajów skał badanego górotworu.

Celem badań zaciskania w skali komór lub struktur wielopoziomowych może być wyznaczenie wpływu czynników geologiczno-górniczych - w tym geomechanicznych na konwergencje. W szczególności takie pomiary umożliwić mogą do klasyfikację górotworu w celu oceny prawidłowości strategii zabezpieczania zabytkowych kopalń. Podano przykład wykorzystania wyników konwergencji przy określaniu metodą elementów skończonych wpływu przekroczenia wytrzymałości na zmianę podatności calizn filarowych. Wyniki obliczeń przy zastosowaniu analizy odwrotnej pokazano na figurze 9.

Wyniki tej pracy służyć mogą bardziej racjonalnym pomiarom konwergencji, a na ich podstawie rozpoznaniu procesów geomechanicznych wywołujących zaciskanie się wyrobisk. 